between shopkeepers and customers has largely disappeared, and the former are no longer the trusted purchasing agents and advisers of the latter; goods are left to sell themselves; the salesman merely wraps them up, sees that they are paid for, and passes them over the counter. The recent foundation of the Retail Trading Standards Association is a move in the right direction, but will not prove effective unless more consumers take an active interest in standards and exert a firm but constructive pressure to secure a fair deal for the consumer.

A SECOND way is for consumers to elect or appoint representatives to protect their interests. Parliament cannot be expected to concern itself with detailed questions, but special consumer councils might succeed if they could arouse public interest. Thirdly, the consumer might be protected by direct Government action. Certain State departments, for example, the Ministry of Health and the Board of Trade, already help in this respect; but they do not go far enough and can only deal with cases that come within the ambit of the law : their services are certain to increase, but no great good can be done unless public opinion is aroused and made effective through a special consumers' organisation. Another method of helping the consumer is suggested by the success of Consumers' Research, Inc., in the United States, a voluntary organisation that investigates goods offered for sale and marketing practices, and makes known the results to its members. Closely allied to the concept of a consumers' research organisation is that of a 'trade union', which would comprise consumers of certain specified products, would stand up for their rights and bring pressure to bear when occasion demanded. An example of such a body is represented by the Automobile Association, which recommends hotels and garages, elaborates route plans and provides free legal defence.

\section{Economics of the U.S.S.R.}

IN a recent issue of the Manchester School, Vol. 6, No. 2, there is an interesting article on "U.S.S.R. Economics-Fundamental Data, System and Spirit" by Prof. M. Polanyi, who points out that the present moment appears to be a favourable one for taking stock of the achievements of the Russian Revolution. Socialism has been definitely instituted, and com. munism has been relegated to an uncertain future. Also the recent introduction of a marketing system makes it easier to review the economic situation, as we can now compute values in terms of money. Planned economy is a corollary of communism, but in fact, Prof. Polanyi states, a system of planned economy has never been attempted in the U.S.S.R. since the repeal of communism in 1921. For one thing, as Stalin bluntly admits, there has never been a proper distributive system at all. The First and Second Five Year Plans were not systems of planned economy, but merely systems of planned production, and even this is an overstatement for no great stress was laid on the systematic nature of the plan. The Soviets claim that they have carried out the First Five Year Plan, but in doing so they pass over in silence the biggest item of their plan, namely, the planned increase of agricultural production by fifty-five per cent ; instead of this being achieved, a very serious fall took place during the first five year period. During the last four years, the outline of an economic system based on the principles of marketing has been developed. Prof. Polanyi concludes that while he is convinced that no return to private ownership is possible in the U.S.S.R., it seems that public and collective manage. ment is developing on lines almost identical with those in the marketing system of capitalism.

\section{Watt Bicentenary Exhibition at the Science Museum}

A spectal exhibition was opened at the Science Museum, South Kensington, on December 20 to com. memorate the bicentenary of the birth at Greenock on January 19, 1736, of James Watt, the famous engineer and inventor. The exhibition will remain open until April 19. Many objects of particular interest are being shown, including three original beam engines, two of which were erected in Soho Manufactory in 1777 and 1788 respectively and the third in London in 1797, and various original experimental models, including the separate condensers of 1765 which led to his most important contribution to the development of the steam engine. The Garret Workshop, where Watt frequently worked from 1790 until his death in 1819 , and which was moved with its contents from Heathfield Hall near Birmingham to the Science Museum in 1924 for permanent preservation, is on view. A large number of drawings, some by Watt himself, have been lent by the Birmingham Public Libraries Committee and form a detailed survey of the progress in steam engine design from 1775 until 1800 , the period of Watt's partnership with Boulton. Numerous portraits of Watt, Boulton and their scientific friends have been generously lent for the occasion by the National Portrait Gallery, the Victoria and Albert Museum, the Royal Society, the City of Birmingham Art Gallery and others. About one hundred letters between Watt and Boulton have been selected from the voluminous correspondence preserved at the Assay Office, Birmingham, which gives an intimate picture of Watt's difficulties and achievements. Some of the memorials and books written on the life and work of Watt are exhibited also. Catalogues of the Memorial Exhibition, the Garret Workshop and the Stationary Engines Collection are on sale in the Science Museum. Special Bicentenary Lectures are being given by the guide lecturer in the lecture theatre and the gallery on various days during the period of the exhibition. Particulars can be obtained on application.

\section{Function of the American Chemical Society}

IN his address at San Francisco on August 19 in receiving the Priestley Medal of the American Chemical Society, Prof. W. A. Noyes said that the two outstanding problems to be solved by our generation are the abolition of war, and a better 
distribution of work and the products of our industries. Chemistry can no longer be thought of as an isolated branch of science, and independent of the rest of our lives. While providing for the development of personality and initiative, it is necessary to restrain those who will not contribute their share in cooperative service. Discussing the growth of the American Chemical Society, Prof. Noyes referred to the proposal to start a journal of organic chemistry as the outcome of a feeling that the Society does not sufficiently provide for the publication of nonindustrial research. Emphasising the fact that chemistry is not an isolated science sharply divided from physics, biology, or even economics, sociology and political science, Prof. Noyes suggested instead the publication of the existing journal in two parts. The first part, published early each month, would contain the papers at present classified under the heading, "General, Physical and Inorganic". The second part, published late in each month, would appear under the sub-heading "Organic and Biological". Both parts would appear under the heading Journal of the American Chemical Society, and the pagination would be continuous. A single index would be issued, but each part would have its own editor. In concluding, Prof. Noyes discussed the question of training, the importance of giving all students a broad knowledge of our chemical heritage, and of encouraging the chemist to see his work as a unit in a co-operative democratic organisation which serves the community and gives a reasonable return to workers, directors and capital.

\section{"Purging" Scientific Literature in Germany}

The Chemiker Zeitung of November 30, p. 978, prints a notice to German chemists requiring them in future to avoid the use of "foreign" words. It is explained that this can easily be accomplished, and among the illustrations given appear the following :

$\begin{array}{lcl}\text { Förderanlage } & \text { instead of Transportanlage } \\ \text { wirtschaftlich } & , & \text { rationell } \\ \text { für, or je } & , & \text { pro } \\ \text { durchlassig } & , & \text { porös } \\ \text { zusammenpressen } & ,, & \text { komprimieren } \\ \text { Nachahmung } & ,, & \text { Imitation } \\ \text { Stück } & , & \text { Exemplar } \\ \text { Ausmasse } & , & \text { Dimensionen } \\ \text { umgrenzen } & , & \text { definieren } \\ \text { Hochstwert } & , & \text { Maximum } \\ \text { Tiefstwert or } & & \\ \text { Niedrigstwert } & , & \text { Minimum. }\end{array}$

Vorbild, Form or Muster are suggested as alternatives to Schema, but the Editor, having perhaps seen comments on this subject in the notice of Joos' "Lehrbuch der theoretischen Physik" and in subsequent correspondence in Nature (September 28, p. 495 , and October 26, p. 675), points out that such innovations as Kleinsehwerkzeug for Mikroskop and Scheidekunst for Chemie should not be adopted, as they might be regarded as ridiculous by others.

\section{New Telephone Developments}

In the Review (No. 3, 1935), published in English by the Ericsson Telephone Factory of Stockholm, there are described two interesting developments of telephony. One of them is called the 'laryngophone' which has been specially designed for use in aircraft. Owing to the noise in airships, ordinary carbon microphones with diaphragms cannot be used. The diaphragm of the new telephone is actuated by being lightly pressed against the throat in the neighbourhood of the larynx. For aircraft, it is necessary to have both hands free, and a headphone of normal design can be conveniently fitted in the pilot's helmet, the laryngophone being worn without discomfort inside his collar, extraneous noise not being trans. mitted by it. This type of instrument can be usefully applied for fire control on warships, in engine rooms, on motor vehicles, tanks, etc. The other instrument is useful in connexion with the buoy-telephones which have for many years been used in the submarines of the Swedish navy. In the latest development, two buoys, with buoy telephones, are used. Each buoy contains a telephone set, and an electric lamp is fitted on the top of it. Flash signals are sent from the submarine to attract attention to the buoy. An instruction plate on the buoy tells how to open the lid of the compartment containing the telephone set, and the submarine is rung up in accordance with the directions printed on a plate on the telephone cover. Buoy telephones are fitted at each end of the submarine. The lamps are supplied from the 110 volt accumulator of the submarine and light up when a watertight telegraph key is closed.

\section{The British Film Institute}

THE British Film Institute's second annual report, issued on October 1, records notable advances (long overdue) in its task of "furthering effective co-operation between those who make, distribute, and exhibit films on the one hand, and all who are interested in the artistic, educational, and cultural possibilities of films on the other". The scope of its activities is indicated by the chapter headings : The Cinema for the Schools, Free Trade in Educational Films, National Film Library, Vouchers of Approval, Entertainment Panel, Dominions, India and Colonies Panel, Medical Panel, Scientific Research Panel, Summer Schools, International. Its regular publications comprise Sight and Sound, on sale to the general public at $6 d$., quarterly; a monthly film review on sale to associate members at $2 d$. ; and news letters circulated to members. In addition, there are occasional leaflets of which the best known, No. 5 , on projection apparatus and films for schools, achieved a circulation of nearly 10,000; another, No. 8, gives a full account of the National Film Library established by the Institute last July. A scheme has been worked out for the award by the Institute of vouchers of approval to films voluntarily submitted to it for examination and, as a corollary of this, expert and authoritative advice is given to producers before and during production. The Entertainment Panel has undertaken a systematic inquiry 